\title{
Chagas disease and globalization of the Amazon
}

\author{
La enfermedad de Chagas y la globalización de la \\ Amazonia
}

\author{
${ }^{1}$ Laboratorio de Ciencias \\ Sociales, Caracas, Venezuela. \\ Correspondencia \\ R. Briceño-León \\ Laboratorio de Ciencias \\ Sociales. \\ Av. Agustín Codazzi, \\ Quinta LACSO, \\ Santa Mónica, \\ Caracas, Venezuela. \\ bricenoleon@yahoo.com \\ bricenoleon@lacso.org.ve
}

\begin{abstract}
The increasing number of autochthonous cases of Chagas disease in the Amazon since the 1970s has led to fear that the disease may become a new public health problem in the region. This transformation in the disease's epidemiological pattern in the Amazon can be explained by environmental and social changes in the last 30 years. The current article draws on the sociological theory of perverse effects to explain these changes as the unwanted result of the shift from the "inward" development model prevailing until the 1970s to the "outward" model that we know as globalization, oriented by industrial forces and international trade. The current article highlights the implementation of five new patterns in agriculture, cattle-raising, mining, lumbering, and urban occupation that have generated changes in the environment and the traditional indigenous habitat and have led to migratory flows, deforestation, sedentary living, the presence of domestic animals, and changes in the habitat that facilitate colonization of human dwellings by vectors and the domestic and work-related transmission of the disease. The expansion of Chagas disease is thus a perverse effect of the globalization process in the Amazon.
\end{abstract}

Chagas Disease; Communicable Diseases; Amazon Ecosystem
Roberto Briceño-León 1

The increase in human cases of Chagas disease in the Amazon has led to the fear it will become an emerging public health problem in the region 1. Chagas disease is not new to the Amazon. Since the early 20th century the infection was known to exist in animals, and in 1924 Carlos Chagas himself described the existence of Trypanosoma cruzi among monkeys in the State of Pará, Brazil 2. The entire Amazon has abundant insects that can transmit the disease. Although species from genus Triatoma, which are widespread elsewhere in South America, are sparsely represented in the Amazon, there are other species such as those of genus Rhodnius that tend to be found in palm leaves, and genus Pastrongylus, in animal dens, eggs, and tree crevices 3,4. Moreover, more than a hundred species of mammals naturally infected by the parasite have been identified in the region 5 . The Amazon therefore displayed nearly all the conditions for the disease to exist, except for the human and social factor, and it was thus considered enzootic.

However, the situation changed in 1969 when the first autochthonous case of Chagas disease was reported 6 , and since then there have been increasing case reports, with 205 cases identified as of 20001 . There have even been cases reported in countries that did not traditionally suffer from the disease, like Guyana 7 and French Guyana 8 . Furthermore, before recognition of the new epidemiological situation, the Pan American Health Organization joined with nine countries 
in Manaus, Brazil, in 2004, to create a new Initiative of Amazonian Countries for the Prevention and Control of Chagas Disease (AMCHA) ${ }^{9}$, which was added to the other three inter-governmental initiatives (the Southern Cone, Central America, and the Andean Region) in the Chagas disease program for the Americas.

The Amazon region is a river basin covering almost seven million square kilometers in nine countries: Brazil, Colombia, Peru, Ecuador, Bolivia, Venezuela, Surinam, Guyana, and French Guyana. For several centuries the human populations in the region were small, with few towns and cities and scattered indigenous populations that maintained an on-going relationship with nature and a unique habitat that was unfavorable to Chagas transmission. This may explain why the Amazon region was considered non-endemic, even though the disease is widely distributed from Mexico to Argentina and Chile 10, having existed on the American continent long before Spanish colonization (studies on mummies 11 have shown that Pre-Colombian populations in the Andean highlands suffered from the disease). The disease is believe to have propagated from some part of Bolivia to highly diverse territories in South America 12, but that it had not spread to the Amazon. The infection had not been detected in the indigenous populations of the Amazon lowlands, and the cases described were in the non-indigenous population, especially in Pará, Brazil, in a population on the outskirts of small towns 13 .

What social and environmental transformations in the Amazon in the last four decades have made Chagas disease appear and increase in incidence? Why has the disease not appeared as in other regions? And on what basis can we state that there is a risk of change in the previously prevailing epidemiological pattern? What are the social and historical origins of these changes, and what is the relevance for the emergence of Chagas disease as a public health problem?

This article analyzes the social and environmental changes in the occupation of the Amazon region, drawing on the sociological theory of perverse effects, and discusses the relationship between development plans for the region and new forms of land occupation and the ways by which they are altering the previous socio-environmental conditions that kept the disease absent or suppressed and that now allow its expansion.

\section{The theory of perverse effects and the development of the Amazon region}

Changes introduced by human activity alter the environment and allow achieving the wellbeing desired by individuals, but they can produce some unwanted effects by creating harmful conditions for human health. Such an effect, referred to as "perverse" in sociology, can result from the aggregation of multiple individual actions, each harmless by itself, but which added together produce a different result from that originally intended, regardless of the actors' wishes and which may even be undesirable for them, but which result from the event's accumulated magnitude 14. Perverse effects can impact both social institutions and nature 15 . The damage potentially caused by human action on social life or nature is not necessarily intentional, since it can occur independently of (or even against) people's wishes 16 . Therefore, the concept is not related to the moral connotation of the term "perverse", but to the autonomy of results vis-à-vis actors' intentions.

We contend that the risk of Chagas disease expansion in the Amazon is a case of perverse effects that societies produce through their impact on nature, an unintended and perhaps undesirable consequence for individuals, but resulting from the magnitude and aggregate modes of human intervention in the natural environment through development plans for the region.

During the 1950s, development studies by CEPAL (ECLAC - Economic Commission for Latin America and the Caribbean) indicated the countries' need for inward development, altering the outward trend that had prevailed throughout Latin America history 17. CEPAL postulated the Center-Periphery theory, with the developed countries in the center, towards which production and trade from the peripheral countries was oriented 18. This development model assumed a spatial expression that was the model of the continent's coastal occupation, with the majority of the population and the important cities located on the outer borders of the territory, leaving the hinterlands, like the Amazon, unpopulated and even abandoned. In many cases the model was that of an agricultural or mining area located in the countryside and connected by railway to a port, through which agricultural products were shipped to world markets; however these production zones had little or no connection to each other, because all transportation networks and production were all outwardly oriented 19 .

The CEPAL proposal for "inward development" involved strengthening the domestic market through import substitution, accelerated 
industrialization, and regional trade integration. Meanwhile, in South America the extension of internal frontiers leading to the occupation of the vast interior saw its maximum expression in the Amazon basin.

The Brazilian government's decision in 1958 to build the Belém-Brasília highway should be interpreted from this perspective, since the decision was to occupy the hinterlands, shifting from the coastal occupation pattern to launch the country's "inward development". Subsequent projects like the North-South Cuiabá-Santarém Highway and the Trans-Amazonian Highway in the 1970s reinforced that same goal. The proposal was repeated in other countries, with different names but the same basic idea. In Venezuela, an ambitious program called the "Conquest of the South" was launched to correct the country's demographic imbalance (with the vast majority of the population in the northern coastal region and only $5 \%$ of the population living in the other half of the country, south of the Orinoco River).

These projects led to important changes in the occupation of the Amazon, but until the 1970s the impact of national "inward development" on land occupation and deforestation was relatively small. Beginning in the 1970s, human migration to the Amazon and deforestation accelerated heavily because the region began to be occupied by social and economic forces that responded to completely different dynamics, namely a new "outward development" framed by the market forces of globalization.

From 1977 to 1988, mean annual deforestation in the Amazon was $21,045 \mathrm{~km}^{2}$, increasing to $22,392 \mathrm{~km}^{2}$ from 2000 to 2005 20. Until 1972, only about 300 hectares had been deforested around the Belém-Brasília highway, but the situation changed drastically and the figure rose to 1,700 hectares by 1977 and 8,200 hectares by 1985 . Most of this deforested area was converted to pasture, a form of land use that had been almost nonexistent, but which now represented the most important cause of deforestation on agricultural operations with more than 5 million head of cattle dedicated to beef exportation 21. During those same 20 years, the Brazilian Amazon population surpassed two million 22 . According to estimates, at the beginning of this process there were approximately 150,000 indigenous people in the Amazon 23 (from 1984 to 1988 and in the Brazilian State of Rondonia alone, an average of 160,000 immigrants arrived per year) 24 .

These changes posed an important risk of transmission of Chagas disease, because through a perverse effect they altered the traditional conditions that had controlled transmission of the infection to humans.

\section{Pattern of indigenous land occupation and Chagas disease}

The absence of Chagas disease in the Amazon reflected the way indigenous peoples had related to their environment and the land occupation patterns these communities had maintained for centuries. These social factors were unfavorable to Chagas vector domiciliation, the key element in transmission of the disease. This, rather than the natural conditions of the Amazon environment (e.g., the hot, humid climate), explains the absence of the disease and provides a basis for understanding the new epidemiological situation.

Anthropological studies in different indigenous populations like the Suruí and Xavánte elucidate the socio-environmental pattern of land occupation by the original inhabitants of the Amazon region 25,26,27. Four aspects in this type of land occupation hinder the vector transmission of Chagas disease: type of human dwellings, continuous mobility, absence of domestic animals, and existence of abundant alternative food sources for potential Chagas vectors.

\section{Type of human dwellings}

Traditionally, the indigenous peoples of the Amazon live in large open communal huts that are not favorable to Chagas vector colonization 28 . Closed dwellings are considered much more favorable to domiciliation, because they offer a pleasant microclimate for the vector and sufficient cracks and crevices to hide from predators during the day. Thus, although indigenous dwellings use materials like palm leaves and tree bark that are propitious to vector presence 29 and have sufficient objects for vectors to hide (as in vector-infested peasant dwellings), colonization has not occurred. Vector domiciliation requires cracks and crevices in the walls or roofs where triatomines can find shelter 30 , and these are not common in the open-walled indigenous communal huts.

\section{Permanent mobility}

The second factor is the continuous mobility of indigenous populations, who regularly move their dwellings and crops. Indigenous communities are accustomed to remaining two or three years in one spot and then abandoning that place because the soil has become depleted. They continually move to search for new land and avoid diseases (such as gastrointestinal) that are spread by human contamination of the space they have occupied. This continuous human mobility did 
not allow Chagas vector adaptation to the dwellings, since entomological studies have shown that domiciliation requires much more time than is allowed by this repeated shifting.

\section{Absence of domestic reservoirs}

The indigenous peoples of the Amazon lowlands do not have domestic animals that could serve as feeding sources for vectors or become reservoirs for the Chagas disease parasite. Indigenous populations may adopt wild animals and keep them in the village, but these animals do not reproduce in captivity, so triatomine domiciliation is not facilitated, and the vectors are not attracted by this food source in or around the dwelling.

\section{Abundant wild food sources}

Finally, but no less important, triatomines remained in their natural environment, and consequently Chagas disease remained as an enzootic, since vectors had an adequate habitat and abundant food sources in the jungle. The triatomine population remained stable, without growing, because of the equilibrium among these factors, favoring their subsistence and that of their predators 31 . If their food sources had become scarce, presumably the vectors would have turned to the human habitat as an alternative, and the factors described above (type of dwelling, mobility, and absence of domestic animals) would have been less capable of resisting vector pressure.

\section{New patterns of land occupation and globalization}

The new processes of occupation of the Amazon territory involve a variety of activities like highway construction, non-indigenous agriculture, cattle-raising, mining, and lumbering, all related to changes in global society and thus responding to the dynamics of outward growth, with cash crops and other commodities exported to the world market. The five patterns of land occupation listed below (as opposed to the indigenous pattern) can modify the Chagas disease profile.

\section{Agricultural pattern}

Agricultural settlement of the Amazon follows two modalities, namely subsistence and commercial agriculture. Subsistence farming employs the traditional slash-and-burn approach, cultivating a plot of land for some two years and then abandoning it and moving on to slash and burn another area. This modality allows grow- ing crops like corn and bananas on small plots that are occupied by way of adverse possession, whose title can be claimed after five years, and which can then be sold to third parties. Although practiced on small plots, the impact of subsistence farming stems from its total magnitude, since an estimated 150,000 families relocated to the Brazilian Amazon alone from 1995 to 1998.

Commercial agriculture has a distinct mode of occupying the territory, since it requires large extensions of land for mechanized production, used mainly to grow soybeans. Soybean farming in the Amazon is a result of globalization, having benefited from: 1) scientific advances that allowed creating a variety that adapts to the wet subtropical climate and 2) the growth of the urban consumer market in China. Brazil exports $18 \%$ of its soybean crop to Asia, particularly China, which requires soybeans and other farm crops to meet the needs of its growing urban population, thus heavily characterizing soybean farming in the Brazilian State of Mato Grosso and in Bolivia.

\section{Cattle-raising pattern}

Initially, plots of land granted for cattle-raising were small and peasant-oriented, but preference was soon given to large cattle ranches, turning huge jungle areas into pasture. This was an effect of globalization, having been favored by the expansion of the beef export market from Brazil to Europe, due both to devaluation of the Brazilian currency and the foot-and-mouth epidemic in Europe, which stimulated beef importation from South America because of consumer fear. Brazil has the world's largest beef exports (with more than double those of Argentina). This growth has impacted not only the Amazon, but also countries like Colombia 32 , where it has become the greatest cause of deforestation (large stretches of land are occupied by huge cattle herds and a small human population, since cattle-raising employs very little labor).

\section{Mining pattern}

Mining in the Amazon region has two modalities 33: (1) formal mining by large companies and (2) traditional production by its competitors in the informal and often illegal activity known as garimpo, including different variations on pan mining and wildcat mining 34,35 . Both are oriented towards the world market and depend on price trends for precious metals on the London, New York, and Tokyo exchanges. Mining has been incriminated with a much greater role in the environmental and social changes in the Amazon than it has actually had. Of course it has produced 
an environmental impact mainly through contamination by the use of mercury in gold mining and has contributed to the increase in malaria in the Amazon, but its impact on the environment is considerably less than that of cattle raising or agriculture, and its impact on Chagas disease is limited, since it does not create stable human settlements because of the specific territorial mobility involved in this type of production.

\section{Lumbering pattern}

The fifth pattern is lumbering. This mode of land occupation is presumed to be one of the most heavily regulated by law, but it is notoriously difficult to control. Short-term lumbering concessions granted in the Amazon region have proven extremely damaging, since they fail to stimulate reforestation by concessionaries. Extraction of the most commercially valuable hardwoods produces much greater damage, since it eliminates other smaller trees and surrounding vegetation and requires tractors to maneuver the large trunks, while affecting the soil by leaving it exposed to the sun. Such lumbering belongs to the world market dynamics, because the depletion of forest resources elsewhere in the world has impelled large companies from Indonesia and Malaysia to seek timber for export not only from Brazil, but also from other parts of the Amazon such as in Guyana and Surinam, where some 25\% of the Amazon has been converted to lumbering by large multinational companies.

\section{Urban pattern}

The last pattern involves the urban settlements, which have expanded, but which cannot be said to play a major role in territorial occupation. Cities in the Amazon serve as ports from which products are shipped abroad, but their size and magnetism for poor populations from the countryside do not play a major role (when displaced by large ranches or plantations, small farmers simply move elsewhere in the countryside). The pattern of occupation of the Amazon requires a "port city" located in or outside the region, and as such the East-West (Brazil-Peru) or so-called "Transoceanic" Highway has been proposed to connect São Paulo to Lima, providing an outlet through Peruvian ports on the Pacific for Brazilian exports to Asian markets, especially China.

Two aspects from the processes described above deserve emphasis. First, even though the processes appear similar (because they all produce deforestation), they are actually different because of the way in which the occupation takes place and the magnitude of the human popula- tion that each requires and allows. Even in similar cases such as slash-and-burn farming, practiced both by indigenous peoples and poor farmers, the latter have a much greater environmental impact because of the far greater number of families involved.

Second, this is a process governed by global dynamics. The original idea of occupying the Amazon as a form of "inward development" no longer exists, although perhaps it was applicable until the 1970s. Other forces later came into play, and thus commercial agriculture and cattle raising clearly demonstrate that "outward development" now prevails in the Amazon, driven by globalization in the sense that external demand governs internal processes, making it more difficult to control such economic dynamics because of the revenue represented for populations, companies, and local and national governments.

\section{New patterns of occupation and their impact on Chagas disease}

The above-mentioned modes of occupation of the Amazon have important consequences for Chagas disease transmission, since they are at the origins of new and traditional transmission modalities in the region 36. Chagas transmission in the Amazon varies (oral, domiciliary vectorial without colonization, and extra-domiciliary vectorial), but all these forms are related to deforestation, human settlement, introduction of domestic animals, and changes in types of human dwellings that allow domiciliary transmission with colonization of the habitat.

\section{Deforestation}

According to official Brazilian government figures, from August 2002 to August 2003, 25,151 km² were deforested, with an additional $27,429 \mathrm{~km}^{2}$ in $2003-2004$, so that a total area of $530,000 \mathrm{~km}^{2}$ has been deforested since 1978. This deforestation process is considered one of the important causes of the emergence of Chagas disease in the Amazon 1. After losing their natural habitat and food sources, vectors are pressured to seek food sources both in the human habitat and in humans themselves.

\section{Human settlements}

However, the search by vectors for alternative food sources among humans would be impossible without stable human populations, precisely the general process occurring at present. Indigenous communities have not settled in one place, 
but have continued moving from place to place in search of fertile land and game, but hundreds of thousands of new immigrants have settled and remained sedentary (non-nomadic) in the region. The magnitude and density vary considerably from one pattern of land settlement to another, since the number of inhabitants living on subsistence farming is high, while it is limited in cattle-raising, and very sparse in lumbering, but all tend to be stable and demographically dense as compared to previous patterns of occupation, thus facilitating both vector domiciliation and transmission of Chagas disease related to certain agricultural activities (such as reported among piassaba palm harvest workers) 37 .

\section{Domestic animals}

Permanent human settlements also lead to the presence of domestic animals in dwellings and the peridomicile. Such animals can be used both as sources of food and company, and the birds, dogs, and cats that remain in the habitat constitute a food source that facilitates vector colonization of dwellings and a reservoir for the Tr. cruzi parasite.

\section{Types of habitat}

This process also changes the typology of housing to predominantly closed dwellings with building materials that favor vector domiciliation. The widespread poor farm dwellings in the Amazon differ very little from rural housing elsewhere in Colombia and Brazil or that which we have studied in Venezuela, with unfinished mud-and-wattle walls, dirt floors, and thatched palm roofs, constituting an ideal environment for Chagas vector colonization 38 . The various forms of indigenous dwellings may persist but are not adopted by immigrants, who are unfamiliar with the indigenous building technology or its sym- bolic and cosmogonic meaning (which might otherwise justify the additional effort required for their construction). New rural dwellings in the Amazon become a risk factor rather than a source a protection against Chagas disease and tend to aggravate intra-domiciliary vectorial transmission 39 .

\section{Conclusions}

The factors that appear to have limited the presence of Chagas disease in the Amazon are changing, and at a face pace 40 . It thus appears plausible to hypothesize an increase in the disease incidence through a process similar to that which occurred several centuries ago in the Andes. At that time, the indigenous population deforested large jungle areas to install a permanent agricultural system, developed a sedentary (non-nomadic) society, and began raising small animals called cuyes (guinea pigs) for food, thus initiating the basis for Chagas vector domiciliation and transmission of the disease. The changes described above in the Amazon appear to point in a similar direction; thus, before too long (although it is difficult to predict exactly when), Chagas disease will likely become an important public health problem in the Amazon.

The Amazon could have a quite different development model, based not on mining, industry, or agribusiness, but on small-scale agro-forestry and silviculture ${ }^{41}$. However such a model has not occurred thus far, because both the domestic and foreign social forces now at work in the Amazon appear not to move in that direction, rather towards globalization of the Amazonian territory. Therefore, the tendencies observed since the 1980s will tend to increase and Chagas disease will spread further in the Amazon, even though none of the actors intended it so, as a perverse effect of globalization in the territorial occupation. 


\section{Resumen}

El incremento de casos autóctonos de la enfermedad de Chagas en la Amazonia a partir de los años setenta hace temer que pueda convertirse en un novedoso problema de salud pública en la región. Este cambio del patrón epidemiológico de la enfermedad en la región amazónica debe ser explicado por las transformaciones ambientales y sociales que han ocurrido en los pasados treinta años. Este artículo utiliza la teoría sociológica de los efectos perversos para explicar esos cambios como el resultado indeseado del cambio de modelo de desarrollo "hacia adentro", que había existido hasta los años setenta, por otro "hacia fuera" que está orientado por las fuerzas de la producción y el comercio internacional que conocemos como globalización. El artículo destaca que la implantación de cin- co nuevos patrones de ocupación agrícola, ganadero, minería, madera y urbano que han generado cambios en el medio ambiente y el hábitat indígena tradicional y que han provocado corrientes migratorios, deforestación, sedentarización de la población, presencia de animales domésticos y modificaciones en el hábitat que facilitan la colonización de las viviendas por los vectores y la transmisión domestica y laboral de la enfermedad. La expansión de la enfermedad de Chagas es un efecto perverso del proceso de globalización de la Amazonia.

Enfermedad de Chagas; Enfermedades Transmisibles; Ecosistema Amazónico

\section{References}

1. Coura JR, Junqueira ACV, Fernandes O, Valente SAS, Miles MA. Emerging Chagas disease in Amazonian Brazil. Trends Parasitol 2002; 18:171-6.

2. Chagas C. Infection naturelle des singes du Pará (Crysotrix, sciureus) par Trypanosoma cruzi. C R Seances Soc Biol Fil 1924; 90:873-6.

3. Gorla D, Jannin J, Salvatella R, Schofield CJ. Perspectivas iniciales para la vigilancia y el control de la enfermedad de Chagas en la región amazónica. In: Reunión Internacional sobre Vigilancia y Prevención de la enfermedad de Chagas en la Amazonía. Washington DC: Organización Panamericana de la Salud; 2004.

4. Schofield CJ Apparent distribution of Triatominae in the Amazon region. In: Guhl F, Schofield CJ, editors. International Workshop on Chagas Disease Surveillance in the Amazon Region. Bogotá: Universidad de Los Andes; 2004. p. 56-63.

5. Deane LM. Animal reservoirs of Trypanosoma cruzi in Brasil. Rev Bras Malariol Doenças Trop 1964; 16:27-48.

6. Shaw J, Lainson R, Fraiha H. Considerações sobre a epidemiologia dos primeiros casos autóctones de doença de Chagas registrados em Belém, Pará, Brasil. Rev Saúde Pública 1969; 3:153-7.

7. Rambadam I. The first autochthonous case of Chagas disease with notes on possible vector in Guyana. Trop Geogr Med 1984; 36:73-6.

8. Beaudet B, Esterre P, Jacquet-Viallet P, Ganty J, Dedet JP. Un cas de cardiopathie chagasique chronique autoctone en Guyane Francaise. Bull Soc Pathol Exotique Filiales 1985; 78:56-63.
9. Organización Panamericana de la Salud. AMCHA iniciativa de los países amazónicos para la prevención y Control de la Enfermedad de Chagas. Washington DC: Organización Panamericana de la Salud; 2004.

10. World Health Organization. Control of Chagas disease: second report of the WHO Expert Committee. Geneva: World Health Organization; 2003. (WHO Technical Report Series, 905).

11. Rothhammer F, Standen V, Nunez L, Allison M, Arriaza B. Origen y desarrollo de la tripanosomiasis en el área Centro-Sur Andina. Revista Chungara 1984; 12:155-60.

12. Schofield CJ. Biosystematics of the Triatominae. In: Service MW, editor. Biosystematics of heaematophagus insects. Oxford: Oxford Univeristy Press; 1988. p. 285-312. (The Systematic Association Special Volume).

13. Souza A, Valente V. Doença de Chagas na Amazônia: situação e perspectivas. Rev Soc Bras Méd Trop 1992; 25 Suppl:29-30.

14. Popper K. La lógica de las ciencias sociales. In: Sánchez-Vásquez A, editor. La lógica de las ciencias sociales. México DF: Editorial Grijalbo; 1969. p. 9-28.

15. Briceño-León R. Los efectos perversos del petróleo. Caracas: Fondo Editorial Acta Científica de Venezuela/Consorcio de Ediciones Carriles; 1991.

16. Boudon R. La logique du social. Paris: Les Éditions Hachette Litérature; 1979.

17. Prebisch R. Problemas teóricos y prácticos del crecimiento económico. Santiago de Chile: Comisión Económica para América Latina y el Caribe; 1973. 
18. Comisión Económica para América Latina y el Caribe. El pensamiento de la CEPAL. Santiago de Chile: Editorial Universitaria; 1969.

19. Quijano A. El proceso de urbanización en América Latina. Santiago de Chile: Comisión Económica para América Latina y el Caribe; 1966.

20. Instituto Nacional de Pesquisas Espaciais. Projeto PRODES: monitoramento de floresta amazônica por satélite. São José dos Campos: Instituto Nacional de Pesquisas Espaciais; 2005.

21. Centre for International Forestry Research. Beef exports fuel loss of Amazonian Forest. CIFOR News Online 2004; 36. http://www.cifor.cgiar.org/ Publications/Corporate/News Online/NewsOnline36/beef_exports.htm.

22. Mahar D. Government policies and deforestation in Brazil's Amazon region. Washington DC: World Bank; 1988.

23. Kohlhepp G. Destruição do meio ambiente e espaço vital na América Latina. In: Cadernos do NERU 1994; 3:13-32.

24. Moran EF. Amazonian deforestation: local causes, global consequences. In: Hansson LA, Jungen B, editors. Human responsibility and global change. Göterborg: University of Göterborg; 1992. p. 54-67.

25. Coimbra Jr. CEA. Human settlements, demographic patterns and epidemiology in Lowland Amazonia: the case of Chagas disease. Am Anthropol 1988; 90:82-97.

26. Coimbra Jr. CEA, Santos RV. Ocupação do espaço, demografia e epidemologia na América do Sul: a doença de Chagas entre as populações indígenas. In: Coimbra Jr. CEA, Santos RV, organizadores. Saúde e povos indígenas. Rio de Janeiro: Editora Fiocruz; 1994. p. 43-62.

27. Coimbra Jr. CEA, Flowers NM, Salzano FM, Santos RV. The Xavante in transition: health ecology and bioanthropology in Central Brazil. Ann Arbor: The University of Michigan Press; 2004.

28. Romaña C. La enfermedad de Chagas. Buenos Aires: López Libreros Editores; 1963.

29. Briceño-León R. La casa enferma. Caracas: Fondo Editorial Acta Científica de Venezuela/Consorcio de Ediciones Carriles; 1990.

30. Schofield CJ, Briceño-León R, Kolstrupp N, Webb DJT, White GB. The role of house design in limiting vector-borne disease. In: Curtis CF, editor. Appropriate technology in vector control. Boca Raton: CRC Press; 1990. p. 187-212.

31. Abad-Franch F. Complejidad ecológica y enfermedad de Chagas en la Amazonia. In: Reunión de l'Initiative Intergouvennamentale de Vigilance et Prevention de la Maladie de Chagas en Amazonie. Cayenne: Organización Panamericana de la Salud/ International Development Research Centre; 2005. p. 19-31.
32. Serrano ED. El modelo ganadero de la Gran Hacienda: un paso atrás en el desarrollo del Caqueta. Florencia: Universidad de la Amazonía; 1990.

33. Cleary D. Anatomy of the Amazon gold rush. Iowa City: University of Iowa Press; 1990.

34. Nogueira F, Papadimacopoulos A. O contexto jurídico do Garimpo de Poconé. Cadernos do NERU 1994; 3:33-57.

35. Silveira SA. Garimpeiros: feios, sujos e maus? In: Pignatti MG, Martins DTO, organizadores. Saúde e ambiente na Região Amazônica. Cuiabá: Editora UFMT; 1999. p. 145-55.

36. Silveira AC. Vigilancia epidemiológica y ambiental de la enfermedad de Chagas en la Amazonía. In: Reunión de l'Initiative Intergouvennamentale de Vigilance et Prevention de la Maladie de Chagas en Amazonie. Cayenne: Organización Panamericana de la Salud/ International Development Research Centre; 2005. p. 1-20.

37. Coura JR, Willcox HPF, Tavares AM, Paiva DD, Fernandes O, Rada ELJC, et al. Aspectos epidemiológicos, sociais e sanitários de uma área no Rio Negro, estado do Amazonas, com especial referência às parasitoses intestinais e à infecção chagásica. Cad Saúde Pública 1994; 10 Suppl 2:327-36.

38. Briceño-León R. Mud, bugs and community participation: remodeling village houses to eradicate vector-borne disease. In: Higginbothan N, Briceño-León R, Jonhson N, editors. Applying health social science: best practice in the developing world. London: Zed Books; 2001. p. 226-45.

39. Coura JR, Junqueira AC, Boia MN, Fernandes O. Chagas disease: from Bush to huts and houses. Is it the case of Brazilian Amazon? Mem Inst Oswaldo Cruz 1999; 94 Suppl 1:379-84.

40. Junqueira A, Albajar R, Coura JR. Doença de Chagas na Amazônia brasileira. In: Coura JR, organizador. Dinâmica das doenças infecciosas e parasitarias. v. 1. Rio de Janeiro: Editora Guanabara Koogan; 2005. p. 595-601

41. Perera MA. El desarrollo sustentable. ¿Base de nuevos males o posibilidad real de crecimiento etnoeconómico? In: Carrillo A, Perera MA, editores. Amazonas: tradición en la modernidad, contribuciones al desarrollo sustentable en el estado Amazonas, Venezuela. Caracas: SADA-Amazonas; 1995. p. 9-42.

Submitted on $04 /$ Oct/2006 Approved on 07/Nov/2006 